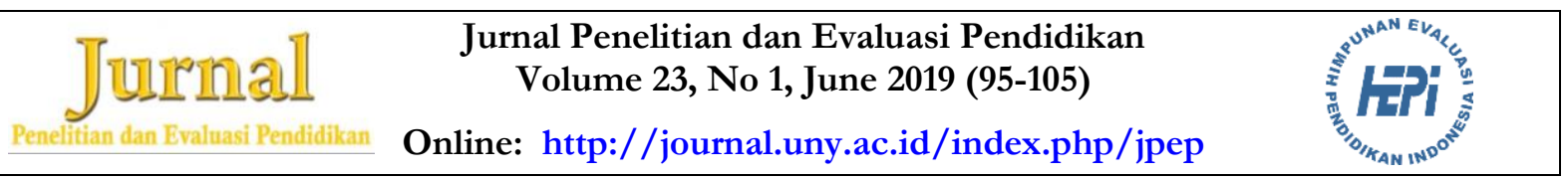

\title{
LEARNING OUTCOME OF MATHEMATICS AND SCIENCE: FEATURES OF INDONESIAN MADRASAH STUDENTS
}

\author{
Kusaeri \\ Universitas Islam Negeri Sunan Ampel Surabaya \\ Ali Ridho \\ Universitas Islam Negeri Maulana Malik Ibrahim Malang
}

\begin{abstract}
This study aims to analyze the learning outcome of mathematics and sciences in the Indonesian National Examination from 2015 to 2018 of MTs (Islamic secondary school). The results of the analysis are used as the basis for making alternative policy as a possible way to improve the quality of mathematics and science learning. With the sample size of 360, 371 MTs students in East Java, the achievement was measured by using 40 multiple choice questions with each having four answer options. Split-plot and latent profile analysis of the data show that there was a consistent decrease in the achievement of mathematics and sciences of the moderate group of MTs from 2015 to 2018 with a dramatic drop in mathematics and tendency to drop for science. The fundamental implication of these findings is that there is a need for learning innovations to improve mathematics and science learning outcomes for 21 st century learning. The findings can also provide data support for decision making for the revision of the mathe-matics and science curriculum and can be further used as empirical evidence for the developed countries in finding ways to improve the quality of mathematics and science learning outcomes for 21 st century learning, in particular, to assist the developing countries such as Indonesia.
\end{abstract}

Keywords: madrasah, mathematics, science, national examination

Permalink/DOI: http://dx.doi.org/10.21831/pep.v23i1.24881

\author{
Contact Kusaeri \\ kusaeriuinsby.ac.id \\ Department of Mathematics Education, Faculty of Tarbiyah and Teacher Tranining, \\ Universitas Islam Negeri Sunan Ampel Surabaya \\ Jl. Ahmad Yani No. 117, Surabaya, 60237, Jawa Timur, Indonesia
}




\section{Introduction}

The 4.0 industrial revolution has become an important topic in education in Indonesia. This is an evident from the refinement of educational curriculum policies at the level of primary, secondary and higher education to accommodate important ideas from the industrial revolution 4.0 (Ibda, 2018; Subekti, Taufiq, Susilo, Ibrohim, \& Suwono, 2018). Therefore, students must be equipped with $21^{\text {st }}$ century skills to prepare them for the competition in the era of the industrial revolution 4.0. The 21 st century skills that students must possess include scientific creativity and innovation, critical thinking, problem solving, literacy, and also metacognitive and collaborative skills (Care, Griffin, \& Wilson, 2018; Isnawati, Indana, \& Susantini, 2018; Jatmiko et al., 2018; Kusaeri \& Aditomo, 2019; Pandiangan, Sanjaya, \& Jatmiko, 2017; Siswanto, Susantini, \& Jatmiko, 2018; Suyidno, Nur, Yuanita, Prahani, \& Jatmiko, 2018; Wahab, Mahmud, \& Tiro, 2018).

Madrasah students in Indonesia have not acquired such 21st-century skills well (Kusaeri, 2018). One of the most visible indicators is student's weak scientific ability and creativity in solving mathematics and science problems. For example, in the last four years of the national examination $(\mathrm{NE})$, madrasah students were worse off when they did the mathematics and science problems that required them to think critically, creatively and to use high-level thinking (Ministry of Education and Culture, 2018). This problem certainly calls for special attention to find a solution so that madrasah students in Indonesia can compete in the era of industrial revolution 4.0.

The possible cause for such low achievement in the two subjects assessed in the NE is the heavy study load of madrasah students. They are required to accomplish not only general subjects (as learned by public school students) but also Islamic lessons (Qur'an, hadith, jurisprudence, aqidah akblaq (Islamic creed and ethics), tasawnf or tariqah (path of spiritual development), history of Islamic culture, nabwu, sorof (Arabic terms) and balagha (rhetoric) (Lukens-Bull, 2010). The learning process at the madrasahs also contributes to such low achievement. Generally, madrasah students tend to be encouraged to remember or memorize the contents of textbooks, especially in madrasahs, managed under the auspices of or affiliated with pesantren (Barkey, 2007). This learning method seems to be incompatible with the principles of mathematics and science learning that mainly require the inquiry process of learning and finding concepts (McClure, 2009).

Madrasahs in Indonesia are always interesting to study because Indonesia is one of the countries with the largest Muslim population in the world (Woodward, 2015). Madrasahs serve as a place of learning and instillation of Islamic values to millions of young Indonesian Muslims. Among the 49,402,000 students in Indonesia, 6,422,260 students study at madrasahs. It indicates that madrasahs have a strategic role in building and coloring the mindset of Indonesian's young generation.

Madrasah has also attracted researchers across the globe. Broadly speaking, studies on madrasah can be categorized into three groups. First, studies have focused on historical reviews of madrasahs and have been intensively carried out since the attack on the New York World Trade Center (WTC) tower, September 11, 2001. Since then, researchers such as Al-Hasani, Ismail, Kazeemkayode, and Elega (2017), Asadullah and Chaudhury (2016), Lukens-Bull (2010), McClure (2009), Nizah (2016), Rao and Hossain (2011) have paid attention to the madrasahs education system. They explored the madrasah curriculum because madrasah as an education institution is assumed to be a place to instill radical Islam for Muslim younger generation. Second, studies are concerned about madrasah management problems such as the study by Ahid (2010). The studies signified that madrasahs with all their limitations leave several problems starting from a limited budget, low student input, underqualified teachers, and limited learning facilities. The studies also spotted how each madrasah transforms to minimize their limi- 
tations. Third, studies have concerned about the achievements of madrasahs. A study by Asadullah and Chaudhury (2016) compares the female and male students ability in mathematics between madrasah students and public schools in Bangladesh. The study of Ali and Furqon (2016) portrays the abilities of Indonesian madrasah students in the NE. Other researchers have concerned about the dynamics of achievement of madrasah students in the context of the NE in the last three years (Kusaeri, 2016, 2018).

The aforementioned studies, however, have mainly discussed the achievement of Indonesian madrasah student in general context and have not specifically focused on student achievement in mathematics and science. Also, previous studies, such as those by Ali et al. (2011) and Ali and Furqon (2016), were carried out within a limited year or a small sample. This calls for a more thorough study on MTs student achievement on specific subject matters tested in the NE in the multi-year period. Therefore, more detail and robust empirical data can be collected to understand madrasah student achievement in Indonesia better. This research, hence, portrays the trends in mathematics and science achievement of MTs students (MTs in Indonesia is equivalent to grade 7-9 of junior high school) and describes the profile of NE participants in the multi-year period for the last four years based on MTs status (publicprivate), number of students, mathematics and science scores.

The focus on MTs is particularly important as the results of the NE at this level will in part become the basis for students' enrolment to the higher level of MA (Islamic senior high school) or SMA (general high school) (Kusaeri, Aditomo, Ridho, \& Fuad, 2018). Low scores in the NE will make it difficult for the students to be enrolled in the school or madrasah they expect. Such situation has encouraged MTs students to be more seriously working on the NE. Hence, the results of the NE in both subjects can highly reflect the student's real abilities. The study of the achievements of MTs students also becomes important in the context of evaluating the quality of learning in MTs (Ali \& Furqon, 2016). Ultimately, which MTs needs more policy support than others can also be more accurately identified.

This research evaluates the MTs student score in mathematics and science in Indonesian NE in the years of 2015-2018. The evaluation is focused on finding alternative solutions and policy to improve the quality of education in Indonesia, especially in the fields of mathematics and science education for MTs students. This evaluation research is expected to draw empirical evidence that provides scientific contributions to developed countries to improve the quality of mathematics and science learning outcomes in the 21 st century, particularly to assist the developing countries to improve their education.

The research questions (RQ) of this study are: (1) what is the MTs (state vs. private) student achievement on mathematics and natural sciences across the examination years? (2) what is the profile of the madrasahs participating in the NE based on the MTs status (state-private), number of students, examination year (2015, 2016, 2017, 2018), mathematics scores, and science scores? (3) what is the alternative solution to the problem related to the mathematics and science learning outcomes found in points 1 and 2 ?

\section{Research Method}

\section{Type and Sample of Research}

This study is a policy research. The sample of this study was MTs in East Java province. In 2018, there were 998,072 students from all over Indonesia taking part in the NE, spread over 17,009 institutions. Most MTs (20.49\%) were in East Java Province (Ministry of Education and Culture, 2018). Considering the big number of MTs in the province, East Java was selected as the sample province. Based on the comprehensiveness of the data obtained continuously from 2015 to 2018, the number of MTs students in East Java involved in this study is 360,371 comprising of 39,834 students (in 
2015), 40,380 (in 2016), 39,740 (in 2017), and 40,417 (in 2018). The students are spread in 630 MTs (46 public, 584 private), 2015 (M = 173.04, $\mathrm{SD}=83.23), 2016(\mathrm{M}=172.89, \mathrm{SD}$ $=82.40), 2017(\mathrm{M}=171.20, \mathrm{SD}=87.88)$, and $2018(\mathrm{M}=181.76, \mathrm{SD}=84.22)$.

Instrument and Procedures

The mathematics and science scores are the results of MTs students in the NE from 2015 to 2018. The mathematics and science questions tested in the NE from 2015 to 2018 consist of 40 multiple-choice items with four answer choices, parallel from year to year. Thus, the results can be used to compare the quality of the schools, students across different schools, or students across different districts/cities or provinces.

Data Analysis

In answering RQ-1, split-plot analysis techniques were used (Pituch \& Stevens, 2016). In this analysis, the status of privatestate madrasahs is between variables, while achievement of the scores in both subjects from year to year becomes within variables. RQ-2 was answered through Latent Profile Analysis (LPA) (Gibson, 1959). The model was estimated by MPlus Version 7 (Muthén \& Muthén, 1998-2015). The score for each variable was converted into a standardized score, $z$. A series of procedures were used to determine the number of profiles, following Meyer, Stanley, and Parfyonova (2012) using Akaike Information Criteria (AIC) (Akaike, 1987), Bayesian Information Criteria (BIC) (Schwarz, 1978), Sample-Adjusted Bayesian Information Criterion (SABIC) (Sclove, 1987), Bootstrapped Likelihood Ratio Test (BLRT) (McLachlan \& Peel, 2000), entropy (Celeux \& Soromenho, 1996; Flaherty \& Kiff, 2012), and likelihood ratio test p-value LMR adjustment (aLMR) ) (Lo, Mendell, \& Rubin, 2001). The smaller the value of AIC and BIC means the more suitable the model (Raftery, 1995). Further, high entropy (close to 1) shows a more fit model (Ramaswamy, Desarbo, Reibstein, \& Robinson, 1993).

\section{Findings and Discussion}

Findings

The study used 630 madrasahs as the sample. Based on this sample, Table 1 presents exposure to mean, standard deviation, and the correlation of all variables.

Table 1. Mean, Standard Deviation, and Pearson Correlation for All Measures

\begin{tabular}{|c|c|c|c|c|c|c|c|c|c|c|c|c|c|c|}
\hline No & Variable & M & SD & 1 & 2 & 3 & 4 & 5 & 6 & 7 & 8 & 9 & 10 & 11 \\
\hline 1 & $\begin{array}{l}\text { Science } \\
2015\end{array}$ & 63.23 & 64.24 & - & - & - & - & - & - & - & - & - & - & - \\
\hline 2 & $\begin{array}{l}\text { Science } \\
2016\end{array}$ & 64.10 & 66.42 & $.964 *$ & - & - & - & - & - & - & - & - & - & - \\
\hline 3 & $\begin{array}{l}\text { Science } \\
2017\end{array}$ & 63.08 & 67.54 & $.952 *$ & $.970^{*}$ & - & - & - & - & - & - & - & - & - \\
\hline 4 & $\begin{array}{l}\text { Science } \\
2018\end{array}$ & 64.15 & 70.55 & $.927 *$ & $.943^{*}$ & $.958^{*}$ & - & - & - & - & - & - & - & - \\
\hline 5 & $\begin{array}{l}\text { Math } \\
2015\end{array}$ & 44.80 & 17.82 & .0452 & .0333 & .0416 & .0378 & - & - & - & - & - & - & - \\
\hline 6 & $\begin{array}{l}\text { Math } \\
2016\end{array}$ & 43.14 & 11.16 & .0024 & -.0121 & -.0073 & -.0118 & - & - & - & - & - & - & - \\
\hline 7 & $\begin{array}{l}\text { Math } \\
2017\end{array}$ & 39.76 & 7.62 & $.114^{*}$ & $.106^{*}$ & $.103^{*}$ & $.104 *$ & $.383^{*}$ & $.475^{*}$ & - & - & - & - & - \\
\hline 8 & $\begin{array}{l}\text { Math } \\
2018\end{array}$ & 37.48 & 5.51 & $.171 *$ & $.176^{*}$ & $.178 *$ & $.176^{*}$ & $.134 *$ & $.187^{*}$ & $.468^{*}$ & - & - & - & - \\
\hline 9 & $\begin{array}{l}\text { Science } \\
2015\end{array}$ & 45.84 & 8.82 & $.198^{*}$ & $.197 *$ & $.195 *$ & $.187^{*}$ & $.149 *$ & $.097^{*}$ & $.163^{*}$ & $.202 *$ & - & - & - \\
\hline 10 & $\begin{array}{l}\text { Science } \\
2016\end{array}$ & 43.88 & 7.57 & $.232^{*}$ & $.226^{*}$ & $232 *$ & $.224 *$ & .0741 & $.083^{*}$ & $.196^{*}$ & $.231 *$ & $.816^{*}$ & - & - \\
\hline $\begin{array}{l}11 \\
12\end{array}$ & $\begin{array}{l}\text { Science } \\
2017 \\
\text { Science }\end{array}$ & 43.15 & $\begin{array}{l}5.22 \\
4.46\end{array}$ & $.217^{*}$ & $.208^{*}$ & $.224 *$ & $.228^{*}$ & .0338 & .019 & $.244^{*}$ & $.240 *$ & $.710^{*}$ & $.751 *$ & - \\
\hline & 2018 & & & $.284 *$ & $.285^{*}$ & $.285^{*}$ & $.277^{*}$ & -.0642 & -.034 & $.110^{*}$ & $.275^{*}$ & $.229 *$ & $.363^{*}$ & $.437^{*}$ \\
\hline
\end{tabular}


The Achievement in Mathematics and Science of State and Private MTs in the NE Across the Years

In general, the trend of average NE scores tends to decline (Figure 1). The decline from year to year was proven to be multivariate, $\mathrm{F}(6,623)=22.49$, partial $\eta 2=.178$, $\mathrm{p}<.05$. Analyzed from the status of the madrasah, there were also differences in scores between state and private madrasahs, $\mathrm{F}(2$, $627)=27.09$, partial $\eta 2=.080, \mathrm{p}<.05$. In addition, the interaction between madrasah status (public-private) and the NE scores across the year $(2015,2016,2017,2018)$ was also proven to be multivariate, $\mathrm{F}(6,623)=$ 9.62, partial $\eta 2=.085, \mathrm{p}<.05$. These results suggest that there is a significant influence of the status of the madrasah (state-private) on the NE scores and the year of examination on the NE scores.

The differences in NE achievement from year to year are explained as follows. The effect of the examination year variable can be considered based on the decrease or increase in $\mathrm{NE}$ achievement. In the mathematics test, the mean of 52.53 (2015) becomes 50.33 (2016), $\mathrm{F}(1,628)=14.07$, partial $\eta 2=.022, \mathrm{p}<.05$. In the following year (2017), it fell to 46.93, $\mathrm{F}(1,628)=5.30$, partial $\eta 2=.002, \mathrm{p}<.05$. The $2018 \mathrm{NE}$ results rose slightly to $47.24, \mathrm{~F}(1,628)=26.71$, partial $\eta 2=.041, \mathrm{p}<.05$.
In the science test, the decline of the mean was 45.24 (2015) to 43.37 (2016), F(1, $628)=41.78$, partial $\eta 2=.062, \mathrm{p}<.05$. In 2017 , it fell to $42.85, F(1,628)=70.58$, partial $\eta 2=.101, \mathrm{p}<.05$. The $2018 \mathrm{NE}$ results rose to $42.91, \mathrm{~F}(1,628)=15.42$, partial $\eta 2=$ $.024, \mathrm{p}<.05$.

In the science test, the decline of the mean was 45.24 (2015) to 43.37 (2016), F(1, $628)=41.78$, partial $\eta^{2}=.062, p<.05$. In 2017 , it fell to $42.85, \mathrm{~F}(1,628)=70.58$, partial $\eta 2=.101, \mathrm{p}<.05$. The $2018 \mathrm{NE}$ results rose to $42.91, F(1,628)=15.42$, partial $\eta 2=.024, \mathrm{p}<.05$

\section{The Profile of MTs Student Taking the NE}

In this study, four profiles were explored (2 to 5 profiles; Table 2). Between the fitting models, the entropy value is the most conclusive criteria among the other criteria. The highest value is obtained in the threeprofiles model. AIC, BIC, and SABIC show reasonable support to these three profiles. Although BLRT shows that the four-profiles model is more suitable than the three-profiles model, aLMR concludes, otherwise, the three-profiles model is better than the fourprofiles model. Based on these compatibility criteria, the most reasonable three-profiles model is selected (Figure 2).

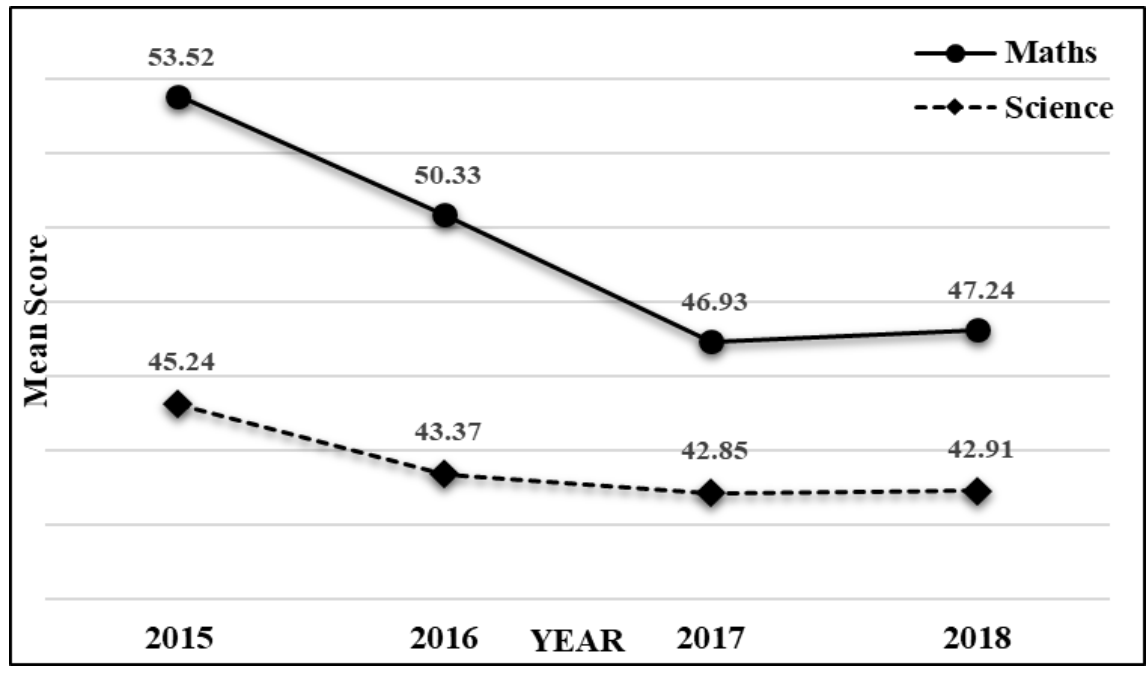

Figure 1. Trend of the Mean of NE Scores of MTs. 
Table 2. Model Fit Indices for the Four Tested Models

\begin{tabular}{lllll}
\hline & 2 Profiles & 3 Profiles & 4 Profiles & 5 Profiles \\
\hline Log likelihood & -30550.824 & -29768.638 & -29303.236 & -28854.721 \\
Free parameters & 37 & 50 & 63 & 76 \\
AIC & 61175.648 & 59637.275 & 58732.472 & 57861.442 \\
BIC & 61340.140 & 59859.561 & 59012.553 & 58199.316 \\
SABIC & 61222.669 & 59700.817 & 58812.535 & 57958.025 \\
aLMR $(p)$ & - & $1545.924(.19)$ & $919.825(.64)$ & $919.721(.53)$ \\
BLRT $(p)$ & $930.697(.00)$ & $930.803(.00)$ & $1564.373(.00)$ & $2182.034(.00)$ \\
Entropy & .986 & .993 & .993 & .975 \\
\hline Note: AIC = Akaike's information criteria; BIC = Bayesian information criteria; SABIC = sample-adjusted Bayesian \\
information criteria; aLMR = adjusted Lo-Mendell-Rubin LR test; BLRT = bootstrap likelihood ratio test.
\end{tabular}

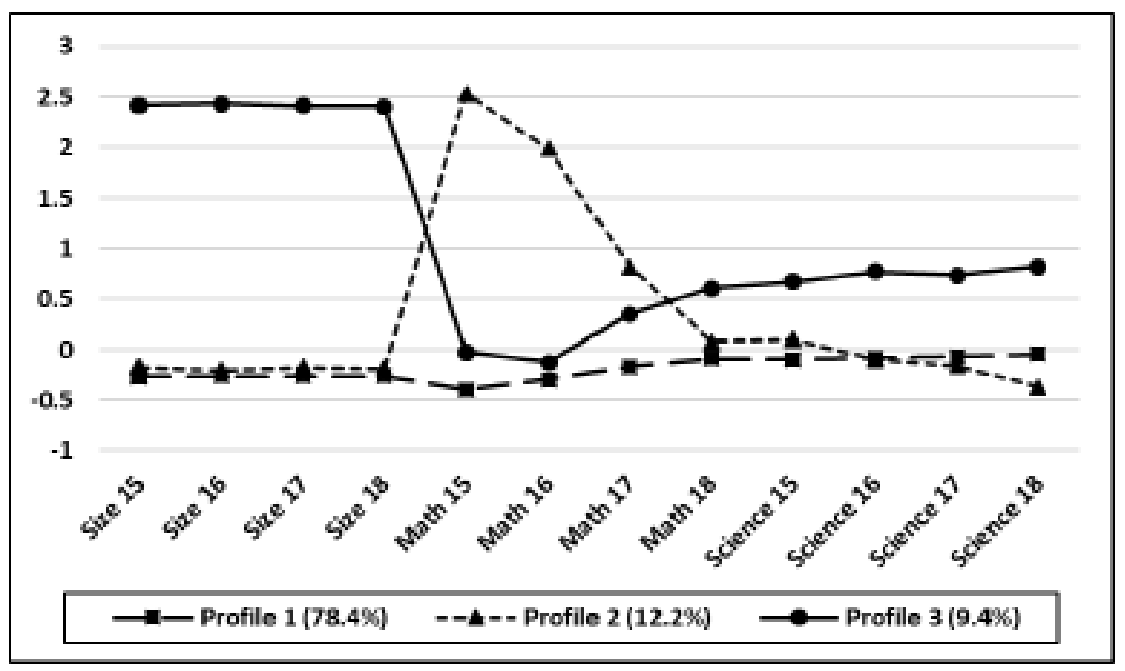

Figure 2. The Final Latent Profile Analysis Result in Z-score

\section{Discussion}

\section{MTs Student Achievement (State-Private) in Math- ematics and Science in the NE in 2015-2018}

The results of the analysis show that in general, there is a trend of decline in MTs student mathematics and science scores in the NE. The decline across the year was proven to be multivariately significant. Analyzed from the status of the madrasahs, there were also differences in achievement between state and private madrasahs. In addition, the interaction between the status of the madrasahs (state-private) and the scores of the NE in the four years $(2015,2016$, 2017,2018 ) was also proven to be multivariately significant.

These results highlight that there is a significant influence on the status of the madrasahs (state-private) and the year of the examination toward student's average score of mathematics and science in the NE. That is, the ability of MTs students to achieve mathematics and science is not yet maximal. Their lack of totality in learning mathematics and science may be because most of them have less ability to associate the benefits of learning the two subjects toward their religious knowledge even in their daily lives. Finally, they may have an idea that studying nonreligious material such as mathematics and science can be ruled out. External factors can also contribute to and influence such a perspective. For example, most madrasahs still prioritize religious learning rather than learning other subjects. It brings an impact on the lack of maximum learning in mathematics and science (Akhwan, 2008). If the madrasahs override it all, madrasah students may not know and even master the material presented in both mathematics and science subjects. 
The Profile of MTs Student Taking the NE based on the Status (State-Private), Number of Students, Year of Examination (2015, 2016, 2017, 2018), Scores in Mathematics and Science

The results of the analysis shows three patterns, namely: (1) Profile 1: small madrasahs, the scores in mathematics and science tend to rise, (2) Profile 2: medium madrasahs, mathematics score decreases, science score tends to decrease, and (3) Profile 3: big madrasahs, mathematics score decreases and then rises, science rises. Profile 2 deserves particular attention because it shows a consistent decrease in both mathematics and natural science. In profile 2, 75 of the 77 are private MTs. The NE mathematics score of the MTs students in this profile is much higher than those in other profiles. The possible explanation is as follows.

In the beginning, the NE became the basis for student graduation. At that time, MTs were competing so that all of their students could pass the NE, although sometimes they used less commendable ways (Kusaeri et al., 2018). For the sake of the good reputation of MTs, finally, any possible ways were taken to get the best NE results. Private MTs with a small and unstable number of students each year play a significant role in contributing to the drop in the NE scores in two subjects. The results of the study of Ali et al. (2011) show a strong correlation between the type of MTs and the number of students. The limited number of students and the lack of stability of the number of students enrolling to private MTs each year has implications to the limited facilities, infrastructure, and the number of teachers. This condition strongly affects the lack of maximum quality learning process (Nurhamzah, 2016).

Private MTs also lack the focus of learning. In addition to their main missions for religious education and character development, many private MTs, mainly those under the auspices of pesantren, have the curriculum highlighting aspects of skills and knowledge to find work after they graduate (Lukens-Bull, 2010). The teachers also contribute to low student achievement. MTs of- ten prioritize primordial over professional aspects. As a result, quality teachers (especially for mathematics and natural science) are very rare.

The learning process in MTs also tends to encourage children to remember or memorize the contents of textbooks. This condition does not only occur in Indonesia, but also in madrasahs located in Pakistan and Bangladesh (Asadullah \& Chaudhury, 2016). When such condition happens in the long term, according to Putra and Kumano (2018), teachers focusing students' memorization will not sufficiently develop students' readiness in science, technology, engineering, and mathematics (STEM) materials.

Alternative Solution and Policy to Improve Education Quality, Especially Mathematics and Science for MTs Students

There are several alternative solutions. (1) The government has the obligation to make policies that can change the mindset on the dichotomy of general knowledge (such as mathematics and science) and the Islamic subjects in MTs. Rao and Hossain (2011) also state that the views of the teachers or managers are dichotomous, and they distinguish Islamic subjects from between general science. (2) The improvement of MTs student mathematics and science learning outcomes can be achieved through the use of media, teaching materials, good quality (valid, practical, and effective) and innovative teaching and learning including: innovative learning models based on inquiry to improve learning outcomes, process performance and also high-level skills (Astutik \& Prahani, 2018; Jatmiko et al., 2016; Pandiangan et al., 2017; Prayogi, Yuanita, \& Wasis, 2018; Siswanto et al., 2018; Suyidno et al., 2018; Yunus, Sanjaya, \& Jatmiko, 2013; Zulkarnaen, Supardi, \& Jatmiko, 2017).

\section{Conclusion}

This study found a consistent decrease in the achievement in the mathematics and natural sciences in the NE from 2015 to 2018 for MTs students in Profile 2. The fundamental implications of the results of this Kusaeri \& Ali Ridho 
study are: (1) innovation in learning development is needed to improve learning outcomes in mathematics and science for the 21st century learning; (2) the data can serve as the main data base for making policy revisions to the curriculum, especially mathematics and science for 21 st century learning; (3) the data provides empirical evidence for developed countries in order to improve the quality of mathematics and science learning outcomes for 21 st century learning and support teaching and learning in the developing countries. Further research can be carried out, especially in the study of the development of innovative teaching and learning in mathematics and science subjects.

\section{Acknowledgments}

The authors would like to express sincere appreciation to the Center for Educational Assessment, the Ministry of Education and Culture of Indonesia for the valuable support to this research.

\section{References}

Ahid, N. (2010). Problem Pengelolaan Madrasah Aliyah dan solusinya [The problems and solutions of Islamic High Schools management]. Islamica: Jurnal Studi Keislaman, 4(2), 336-353.

Akaike, H. (1987). Factor analysis and AIC. Psychometrika, 52(3), 317-332.

Akhwan, M. (2008). Pengembangan Madrasah sebagai pendidikan untuk semua [Madrasa development as education for all]. El-Tarbawi, 1(1), 4154.

Al-Hasani, S. M. A., Ismail, A. R., Kazeemkayode, B., \& Elega, D. A. Q. (2017). Creating a practicing Muslim: A study of Qawmi Madrasah in Bangladesh. British Journal of Education, Society \& Behavioural Science, 20(3), 1-9.

Ali, M., \& Furqon. (2016). Madrasah students' achievement study in Indonesia. Global and Stochastic Analysis, 3(3), 181-190.
Ali, M., Kos, J., Lietz, P., Nugroho, D., Furqon, Zainul, A., \& Emilia, E. (2011). Quality of education in madrasab: Main study. Jakarta: Ministry of Religious Affair.

Asadullah, M. N., \& Chaudhury, N. (2016). To madrasahs or not to madrasahs: The question and correlates of enrolment in Islamic schools in Bangladesh. International Journal of Educational Development, 49, 55-69.

Astutik, S., \& Prahani, B. K. (2018). The practicality and effectiveness of collaborative creativity learning (CCL) model by using PhET simulation to increase students' scientific creativity. International Journal of Instruction, 11(4), 409-424.

Barkey, J. P. (2007). Madrasas medieval and modern: Politics, education, and the problem of Muslim identity. In R. W. Hefner \& M. Q. Zaman (Eds.), Schooling Islam: The Culture and Politics of Modern Muslim Education (pp. 40-60). Princeton, NJ: Princeton University Press.

Care, E., Griffin, P., \& Wilson, M. (Eds.). (2018). Assessment and teaching of 21st century skills: Research and applications. New York, NY: Springer.

Celeux, G., \& Soromenho, G. (1996). An entropy criterion for assessing the number of clusters in a mixture model. Journal of Classification, 13(2), 195-212.

Flaherty, B. P., \& Kiff, C. J. (2012). Latent class and latent profile models. In $\mathrm{H}$. Cooper, P. M. Camic, D. L. Long, A. T. Panter, D. Rindskopf, \& K. J. Sher (Eds.), APA bandbook of research methods in psychology, Vol 3: Data analysis and research publication (pp. 391-404). Washington, DC: American Psychological Association.

Gibson, W. A. (1959). Three multivariate models: Factor analysis, latent structure analysis and latent profile analysis. Psychometrika, 24, 229-252. 
Ibda, H. (2018). Penguatan literasi baru pada guru Madrasah Ibtidaiyah dalam menjawab tantangan era revolusi industri 4.0 [Strengthening new literacy for Madrasah Ibtidaiyah teachers in responding to the challenges of the 4.0 industrial revolution era]. JRTIE: Journal of Research and Thought of Islamic Education, 1(1), 1-21.

Isnawati, Indana, S., \& Susantini, E. (2018). Using metacognitive strategy to teach learning strategies: A study of Indonesian pre-service biology teachers. The New Educational Review, 52(2), 258-268.

Jatmiko, B., Prahani, B. K., Supardi, Z., Wicaksono, I., Erlina, N., Pandiangan, P., \& Althaf, R. (2018). The comparison of OR-IPA teaching model and problem based learning model effectiveness to improve critical thinking skills of pre-service physics teachers. Journal of Baltic Science Education, 17(2), 1-22.

Jatmiko, B., Widodo, W., Martini, Budiyanto, M., Wicaksono, I., \& Pandiangan, P. (2016). Effectiveness of the INQF-based learning on a general physics for improving student's learning outcomes. Journal of Baltic Science Education, 15(4), 441-451.

Kusaeri, K. (2016). Studi perilaku cheating siswa madrasah dan sekolah Islam ketika ujian nasional [Study of cheating behavior of madrasah students and Islamic schools on national exams]. Edukasia: Jurnal Penelitian Pendidikan Islam, 11(2), 331-354.

Kusaeri, K. (2018). The portrait of Madrasah Aliyah in Indonesia: A critical evaluation of the mathematics score in the national examination. Journal of Physics: Conference Series, 1028, 1-7.

Kusaeri, K., \& Aditomo, A. (2019). Pedagogical beliefs about critical thinking among Indonesian mathematics pre-service teachers.
International Journal of Instruction, 12(1), 573-590.

Kusaeri, K., Aditomo, A., Ridho, A., \& Fuad, A. Z. (2018). Socioeconomic status, parental involvement in learning and student' mathematics achievement in Indonesian senior high school. Jurnal Cakerawala Pendidikan, 37(3), 333-344. https://doi.org/10.21831/cp.v38i3.2 1100

Kusaeri, K., Hamdani, A. S., Suparto, S., \& Irmanila, E. (2018). Komparasi kredibilitas penyelenggaraan UNBK dan UNKP pada pelajaran matematika [Comparison of the credibility of the implementation of UNBK and UNKP in mathematics]. Jurnal Ilmu Pendidikan, 24(1), 10-18.

Lo, Y., Mendell, N. R., \& Rubin, D. B. (2001). Testing the number of components in a normal mixture. Biometrika, 88(3), 767-778.

Lukens-Bull, R. (2010). Madrasa by any other name: Pondok, pesantren, and Islamic schools in Indonesia and larger Southeast Asian region. Journal of Indonesian Islam, 4(1), 1-21.

McClure, K. R. (2009). Madrasas and Pakistan's education agenda: Western media misrepresentation and policy recommendations. International Journal of Educational Development, 29(4), 334341.

McLachlan, G., \& Peel, D. (2000). Finite mixture models: Wiley series in probability and statistics. New York, NY: Wiley.

Meyer, J. P., Stanley, L. J., \& Parfyonova, N. M. (2012). Employee commitment in context: The nature and implication of commitment profiles. Journal of Vocational Behavior, 80(1), 1-16.

Ministry of Education and Culture. (2018). Laporan hasil ujian nasional tabun pelajaran 2017/2018 [Report on the results of the 2017/2018 national examinations]. Jakarta: Centrer for Educational Assessment, Ministry of Education and Culture of Republic of Indonesia. 
Muthén, L. K., \& Muthén, B. O. (19982015). Mplus user's guide (7 ed.). Los Angeles, CA: Muthén \& Muthén.

Nizah, N. (2016). Dinamika Madrasah Diniyah: Suatu tinjauan historis [Dynamics of Madrasa Diniyah: A historical review]. Edukasia: Jurnal Penelitian Pendidikan Islam, 11(1), 181 202.

Nurhamzah, N. (2016). The analysis of determinants factors in improving the quality of madrasah. International Journal of Scientific \& Technology Research, 5(1), 1-4.

Pandiangan, P., Sanjaya, I. G. M., \& Jatmiko, B. (2017). The validity and effectiveness of physics independent learning model to improve physics problem solving and selfdirected learning skills of students in open and distance education systems. Journal of Baltic Science Education, 16(5), 651-665.

Pituch, K. A., \& Stevens, J. P. (2016). Applied multivariate statistics for the social sciences (6 ed.). New York, NY: Routledge.

Prayogi, S., Yuanita, L., \& Wasis. (2018). Critical inquiry based learning: A model of learning to promote critical thinking among prospective teachers of physics. Journal of Turkish Science Education, 15(1), 43-56.

Putra, P. D. A., \& Kumano, Y. (2018). Energy learning progression and STEM conceptualization among preservice science teachers in Japan and Indonesia. The New Educational Review, 53(3), 153-162.

Raftery, A. E. (1995). Bayesian model selection in social research. Sociological Methodology, 25, 111-163.

Ramaswamy, V., Desarbo, W. S., Reibstein, D. J., \& Robinson, W. T. (1993). An empirical pooling approach for estimating marketing mix elasticities with PIMS data. Marketing Science, 12(1), 103-124.

Rao, N., \& Hossain, M. I. (2011). Confronting poverty and educational inequalities: Madrasas as a strategy for contesting dominant literacy in rural Bangladesh. International Journal of Educational Development, 31(6), 623-633.

Schwarz, G. (1978). Estimating the dimension of a model. Annals of Statistics, 6, 461-464.

Sclove, S. L. J. P. (1987). Application of model-selection criteria to some problems in multivariate analysis. Psychometrika, 52(3), 333-343.

Siswanto, J., Susantini, E., \& Jatmiko, B. (2018). Multi-representation based on scientific investigation for enhancing students' representation skills. Journal Physics: Conference Series, 983, 012034.

Subekti, H., Taufiq, M., Susilo, H., Ibrohim, \& Suwono, H. (2018). Mengembangkan literasi informasi melalui belajar berbasis kehidupan terintegrasi STEM untuk menyiapkan calon guru sains dalam menghadapi era revolusi industri 4.0: Review literatur. Education and Human Development Journal, 3(1), 81-90.

Suyidno, S., Nur, M., Yuanita, L., Prahani, B. K., \& Jatmiko, B. (2018). Effectiveness of creative responsibility based teaching (CRBT) model on basic physics learning to increase student's scientific creativity and responsibility. Journal of Baltic Science Education, 17(1), 136-151.

Wahab, A., Mahmud, A., \& Tiro, M. A. (2018). The effectiveness of a learning module for statistical literacy. The New Educational Review, 53(3), 187-199.

Woodward, K. E. (2015). Indonesian schools: Shaping the future of Islam and democracy in a democartics 
Muslim country. Journal of International Education and Leadership, 5(1), 1-14.

Yunus, S., Sanjaya, I. G. M., \& Jatmiko, B. (2013). Implementasi pembelajaran fisika berbasis guided inquiry untuk meningkatkan hasil belajar siswa auditorik [Implementation of physics learning based on guided inquiry to improve auditory learners outcomes]. Jurnal Pendidikan IPA Indonesia, 2(1), 48-52.
Zulkarnaen, Supardi, Z. A. I., \& Jatmiko, B. (2017). Feasibility of creative exploration, creative elaboration, creative modeling, practice scientific creativity, discussion, reflection (C3PDR) teaching model to improve students' scientific creativity of junior high school. Journal of Baltic Science Education, 16(6), 1020-1034. 